doi: 10.3935/rsp.v26i2.1657

\section{DUGOTRAJNA SKRB ZA STARIJE OSOBE: IZAZOV ZA SOCIJALNU GERONTOLOGIJU I SOCIJALNU POLITIKU}

Pitanja povezana sa starenjem i starošću postoje od kada živi čovjek. Filozofi, pjesnici, političari, svećenici i razni mislioci uvijek su se bavili takvim izazovima. Međutim, do kraja Prvoga svjetskog rata ne možemo govoriti o planiranom istraživanju starosti. Prekretnicu predstavlja osnivanje prvog instituta za proučavanje problema starenja 1928. godine na Sveučilištu Stanford u SAD-u. ${ }^{1} \mathrm{U}$ to vrijeme rođena je nova znanost, gerontologija, koja ispituje uzroke i uvjete starenja kao i promjene $u$ ponašanju i iskustvu povezane sa starenjem.

Gerontologija (grč. geron - starac, star; logos - znanost, nauka, proučavanje) je znanost o starosti, starenju i starim ljudima koja se bavi socijalnim i medicinskim aspektima starenja. U početnom razvoju znanosti gerontolozi su uglavnom naglašavali medicinske aspekte starenja, a kasnije gerontologiju dopunjavaju znanjem iz sociologije, psihologije i demografije. Danas gerontologiju oblikuju i druge znanosti. $\mathrm{Na}$ području društvenih znanosti najprisutnija je tzv. socijalna gerontologija.

Socijalna gerontologija istražuje kako društvena struktura utječe na populaciju starijih osoba, posebno na njihovo osobno iskustvo starenja i obrnuto kako starije osobe i njihova iskustva sa staranjem utječu na cjelokupnu društvenu strukturu. Bavi se društvenim odgovorima na demografske promjene i utjecajem tih odgovora na populaciju starijih osoba. Zahvaljujući tako širokom području istraživanja, mnogi

1 Požarnik, H. (1981). Umetnost staranja: Leta, predsodki in dejstva. Ljubljana: Cankarjeva založba. doi: $10.3935 /$ rsp.v26i2.1660

\section{LONG-TERM CARE OF OLDER PEOPLE: THE CHALLENGE FOR SOCIAL GERONTOLOGY AND SOCIAL POLICY}

Questions associated with ageing and old age have existed since the beginning of humankind. Philosophers, poets, politicians, priests and various thinkers have often engaged in such challenges. The threshold that signified a change was the establishment of the National Institute on Aging in 1928 at Stanford University in the USA $^{1}$. This is when new science was born, i.e. gerontology, which addresses the reasons and circumstances of ageing, as well as changes in behaviour and experience linked with old age.

Gerontology (geron - Gr. old, oldman; logos-science) is the science or knowledge of old age, ageing and older people and it deals with the social and medical perspectives of ageing. At the beginning of its development, the gerontologists predominantly highlighted the medical perspectives of ageing; however, later on gerontology was complemented by knowledge from the field of sociology, psychology and demography. Now, other sciences form gerontology. In the area of social sciences the one that is most present is social gerontology.

Social gerontology explores in what way the social structure has an impact on the population of older people, especially their personal experience with ageing and vice versa, how older people and their experience with ageing have an impact on the whole social structure. It involves the social response to demographic change and the impacts of these responses to the population of older people. Due to its extensive area of

\footnotetext{
${ }^{1}$ Požarnik, H. (1981). Umetnost staranja: Leta, predsodki in dejstva. Ljubljana: Cankarjeva založba.
} 
gerontolozi uključeni su u razvoj politike za starije osobe, pri čemu posebnu pažnju posvećuju razvoju različitih oblika intervencija u praksi. Potonje je vodilo i ovo tematsko izdanje Revije za socijalnu politiku u kojem smo prikupili neka od najnovijih istraživanja na području socijalne gerontologije, za koje vjerujemo da su trenutno relevantna za donositelje odluka u socijalnoj politici.

Prikupljeni prilozi u većoj mjeri predstavljaju nalaze iz Slovenije i Hrvatske, koje autori vješto povezuju sa suvremenom međunarodnom literaturom, kako bi pokazali aktualnost i relevantnost nacionalno specifičnih tema u međunarodnom kontekstu. Čitatelji ovog broja također mogu usporediti aktualna pitanja socijalne gerontologije između dviju država i smjestiti ih u kontekst socijalne politike koja ima zajedničke korijene jer tradicija društvene politike obiju država još uvijek odražava neke zajedničke točke. S druge strane, prilozi, također, otkrivaju mogućnosti koje obje države mogu međusobno razvijati na području organiziranja skrbi za starije osobe. U Sloveniji se već više od desetljeća radi na zakonu o dugotrajnoj skrbi, dok je u Hrvatskoj ovo područje novo. Unatoč nerazvijenosti zakonodavstva o dugotrajnoj skrbi, možemo pronaći primjere dobre prakse, istraživanja i rasprave o tome kakav bi trebao biti budući sustav dugoročne skrbi u obje zemlje.

U sedam znanstvenih članaka, dvije recenzije znanstvenih monografija i dokumentaciji, ovaj put tematsko izdanje Revije nudi zanimljivu usporedbu suvremenih socijalnogerontoloških nalaza relevantnih za socijalnu politiku dviju zemalja, bivših članica zajedničke države. Prilozi, upravo zbog svoje analitičke prirode i kritike postojećih sustava socijalne politike, mogu privući širi krug čitatelja.

Prvi članak Long-term care determinants of care arrangements for older research, many gerontologists are involved in developing the policy of older people and give special attention to developing various forms of interventions in practice. The latter is the guideline of the present thematic issue of Croatian Review of Social Policy (Revija za socijalnu politiku) in which some of the newest findings from the area of social gerontology are collected, the ones that we feel are relevant now for all decision-makers in the field of social policy.

The contributions collected here mainly represent the findings from Slovenia and Croatia that the authors skilfully link with contemporary international literature to show its topicality and relevance in relation to the nationally specific subject matters in the international context. The readers of the present issue may also compare the topical questions in social gerontology between both countries and place them in the context of social policy that has common grounds, since the tradition of social policy of both countries still reflects some common points. On the other hand, the contributions also reveal the opportunities that both countries may mutually develop in the area of organising care for older people. Among such fields is the field of long-term care that has had a decade long period of adopting legislation in Slovenia, but in Croatia this is a new area. In spite of the underdeveloped legislation on long-term care in both countries, good practice can be found, as well as research and discussion on what the system of long-term care should be like.

The present special thematic issue with seven scientific articles, two reviews of scientific monographs and documentation offers an interesting comparison of contemporary social and gerontological findings which are relevant for the social policy of the two formerly federal states. Due to the analytical nature and critique of the existing systems, the contributions may also be interesting also for a broader circle of readers. 
people in Europe: Evidence from SHARE autora Valentine Hlebec, Andreja Srakara $i$ Borisa Majcena, naglašava sličnosti i razlike u sustavima dugoročne skrbi između država članica Europske unije. Organizacija formalne skrbi za starije osobe ima snažan utjecaj na integraciju formalne i neformalne skrbi. Što države imaju bolje razvijene sustave formalne skrbi, to je veća primjena formalnih oblika pomoći, a manja je uloga neformalnog sektora. Da bi ljudi u starijoj dobi imali istinski zadovoljene potrebe, često je potrebno kombinirati formalne i neformalne oblike pomoći. U članku su prikazani rezultati analize socijalnih odrednica različitih oblika skrbi za starije među članicama Europske unije.

U drugom članku pod naslovom A comparative analysis of people's views on future policies for older people, autorice Maša Filipovič Hrast, Mi Ah Schoyen i Tatjana Rakar predstavljaju rezultate zanimljive ankete o mišljenjima građana četiriju zemalja u pogledu budućeg sustava skrbi za starije i politike umirovljenja. U istraživanju su sudjelovali građani Norveške, Slovenije, Njemačke i Velike Britanije, zemalja s različitim sustavima socijalne zaštite, što čini sličnosti i razlike u njihovim očekivanjima izuzetno zanimljivim.

U nastavku, na temelju specijalizirane metode istraživanja tzv. brze procjene potreba i usluga dugotrajne skrbi (engl. Rapid assessment of needs and services in long-term care), Jana Mali $i$ Vera Grebenc prikazuju opseg, prirodu i raspodjelu dugotrajne skrbi i predlažu efikasne odgovore na potrebe starijih osoba u jednoj od manjih općina u Sloveniji. Zbog nedostatka rješenja na nacionalnoj razini važno je da pomoć za starije osobe organiziraju i lokalne sredine. U konkretnom slučaju, riječ je o organizaciji lokalne pomoći u općini i o regionalnoj integraciji.

Posebno područje dugotrajne skrbi je neformalna skrb, koja se često razumije
The first contribution, Long-term care determinants of care arrangements for older people in Europe: Evidence from SHARE by Valentina Hlebec, Andrej Srakar and Boris Majcen emphasises the similarities and differences in the systems of long-term care of the EU member states. The organisation of formal care for older people has a great impact on the link between the formal and informal care. The more the states have developed systems of formal care, the greater is the use of formal forms of help and the smaller the role of informal sector. In order for people to have their needs met in old age, the formal and informal forms of help need to be combined. The contribution shows the results of the analysis of social determinants of various forms of care for older people among the EU member states.

The second contribution titled A comparative analysis of people's views on future policies for older people by Maša Filipovič Hrast, Mi Ah Schoyen and Tatjana Rakar shows the results of an interesting research conducted on the views of the citizens from four states regarding the future system of older people's care and the policy of retirement. The citizen from Norway, Slovenia, Germany and Great Britain participated in the research. All these countries have different systems of social welfare, therefore the similarities and differences in the citizens' expectations are all the more interesting.

Further on, Jana Mali and Vera Grebenc suggest effective response to older people's needs in one of smaller municipalities of Slovenia, based on a specialised method of research, the rapid assessment of needs and services in long-term care that shows the extent, the nature and the distribution of longterm distress. Due to the lack of solutions on the national level, it is essential that the help for older people is also organised on the local level. In the case presented here, 
kao ekvivalentno područje formalne skrbi. Vrlo je važno poznavati mnoge dimenzije neformalne skrbi, koje u članku Profil neformalnih njegovatelja starijih osoba $u$ gradu Zagrebu predstavljaju autorice Ana Stambuk, Silvia Rusac i Lea Skokandić. One ukazuju na to da su neformalni njegovatelji vrlo heterogena skupina ljudi, koja zaslužuje posebnu pomoć i podršku na području socijalne politike te su nam stoga potrebne daljnje različite studije o tome $\mathrm{u}$ kojim područjima i kako možemo osigurati tu pomoć.

Na razini formalne skrbi za stare osobe Slovenija i Hrvatska imaju dugu tradiciju formalnog zbrinjavanja u domovima za starije. Što možemo očekivati u ovom području u budućnosti, kako su domovi spremni za novi sustav dugotrajne skrbi i kako se mogu razvijati u kontekstu dugotrajne skrbi, samo su neka od pitanja kojima se bavi Jana Mali u prilogu Innovations in long-term care: The case of old people's home in Slovenia. Ona predstavlja rezultate analize slovenskih domova, koji dokazuju da su inovacije u domovima ono što domove postavlja u područje dugotrajne skrbi. Socijalne inovacije, inovacije socijalne zaštite i inovacije u domovima, zapravo su danas one koje slijede demografski trend starenja i na djelotvoran način odgovaraju na potrebe starijih osoba.

Za razvoj buduće socijalne politike, također su važna saznanja određenih, specifičnih područja, koja prožimaju populaciju starijih osoba. Ovaj put smo posebnu pozornost posvetili pitanjima siromaštva među starijim ženama i samoubojstvima muškaraca koji žive u ruralnim područjima.

Vesna Leskošek u članku Poverty of older women in Slovenia upozorava da je siromaštvo kod starijih žena dva do tri puta veće nego kod muškaraca. Sustavi socijalne skrbi često ovu vrstu siromaštva rješavaju neefikasno jer se ne javlja samo tijekom starosti, već je uvjetovana život- this involves the organisation of community care within the municipality and regional networking.

A special field of long-term care is informal care, often seen as the field that is equivalent to formal care. It is therefore essential to know various dimensions of informal care that are shown by Ana Štambuk, Silvia Rusac and Lea Skokandić in the article titled The Profile of Informal Caregivers of Older People in the City of Zagreb in Zagreb. The authors draw attention to the fact that informal care-providers are a distinctly heterogeneous group of people who deserves special help and support in the field of social policy, therefore various studies in the areas and ways of providing help for them are needed.

On the level of formal care for older people, Slovenia and Croatia share a long tradition of formal care provided in older people's homes. What can be expected in this area in the future, how the older people's homes are prepared for a new system of long-term care and how they will develop in the context of long-term care are only a few of the questions dealt with by Jana Mali in her contribution titled Innovations in long-term care: The case of old people's home in Slovenia. The author presents the results of the analysis of the Slovenian older people's homes that prove the innovation in older people's homes to be those that place such homes in the field of long-term care. The social innovation, the innovations in social welfare and older people's homes' innovations are now those that follow the demographic trends of ageing population and effectively respond to the needs of older people.

For the development of social policy in the future, the findings of some specific fields that are characteristic for the population of older people are also relevant. This time, the question of poverty among older 
nim stilom, socijalizacijom žena i ulogom žena u društvu. Svi ti čimbenici utječu na stjecanje dohotka i kasniji iznos mirovine. Prikazani su i analizirani podatci za Sloveniju, koji se također mogu usporediti sa stanjem u Hrvatskoj.

Prilično nova i zabrinjavajuća tema predstavljena je od autora Philippe Roy $i$ Duška Knežević Hočevar u članku Listening to a silent crisis: Men's suicide in rural and farming communities in Slovenia. Ozbiljnost samoubojstava među starijim muškarcima u ruralnim područjima prikazuju kao socijalni i zdravstveni problem koji bi trebao izazvati zabrinutost i pažnju u budućim politikama skrbi za starije osobe. Pitanja spola, uloge starijih muškaraca u društvu i odnosa između tradicionalne uloge muškaraca i ruralnih vrijednosti, predstavljaju novo važno područje u planiranju razvoja skrbi za visoko rizičnu podskupinu starijih osoba.

U rubrici dokumentacije objavljujemo i članak Lee Lebar i Mateje Nagode, Trends and challenges in long-term care in Europe. Predstavljanjem organizacije sustava dugoročne skrbi u Europi one ukazuju i na izazove povezane s institucionalnom i geografskom rascjepkanošću pružanja dugoročne skrbi, trendove u promicanju skrbi u zajednici nasuprot institucionalnim, povlačenje javnih usluga u odnosu na privatne $\mathrm{i}$ jačanje neformalne skrbi.

Na kraju, u duhu aktualnih pitanja socijalne gerontologije i socijalne politike, odabrali smo pregled dviju monografija koje su objavljene 2018. godine. Sadržaji obiju važni su za ovo izdanje tematskog broja jer ih često ne povezujemo ili razumijemo odvojeno. Predstavljamo recenzije knjiga Maše Filipovič Hrast i Tatjane Rakar »Socialna politika danes in jutri« i Ane Štambuk »Stavovi starijih osoba prema smrti $i$ umiranju.«

Pozivamo vas da pročitate $\mathrm{i}$ razmislite o aktualnim temama koje donosi starenje women and suicide rate of men living in rural areas is examined.

In her article Poverty of older women in Slovenia, Vesna Leskošek points out that the poverty of older women is two to three times higher than the poverty of older men. The systems of social care often solve such poverty inefficiently, because it does not appear only in old age, but is rather conditioned by lifestyle, socialisation and the role of women in society. All these factors have an impact on earning an income and the amount of pension later on. The data for Slovenia is shown and analysed and they can be comparable to the circumstances in Croatia.

A fairly new and worrying subject matter is presented by Philippe Roy and Duška Knežević Hočevar in their contribution titled Listening to a silent crisis: Men's suicide in rural and farming communities in Slovenia. The severity of suicide among older men in rural areas is presented as a social and health problem that should raise concern in the future policy of care of older people. Those of us who may affect the field of the development of care for older people should be more aware of the question of gender, the roles of older men in society and the circumstances of the traditional role of men and farming values.

A section Documentation presents the article by Lea Lebar and Mateja Nagode, titled Trends and challenges in long-term care in Europe. With the listing of the organisation of the systems of long-term care in Europe, they present the challenges associated with institutional and geographic fragmentation in the provision of longterm care, the trends in the stimulation of community care as opposed to institutional care, the withdrawal of public services as opposed to personal services and the strengthening of informal care.

In the end, in spirit of the topical questions of social gerontology and social policy we have decided to present two monographs 
i starost jer je upravo starenje tema koja je zajednička svim ljudima. Bez obzira na spol, rasu, nacionalnost i druge društvene karakteristike svi mi starimo i približavamo se posljednjem razdoblju života.

\section{Gostujuće urednice: Jana Mali i Ana Štambuk}

Ljubljana i Zagreb, 31. 5. 2019. published in 2018. The content of both monographs is relevant for this special thematic issue, since they are often not linked or they are seen separately. We present the review of the book by Maša Filipovič Hrast and Tatjana Rakar titled Social policy today and tomorrow and the book by Ana Stambuk titled Stavovi starijih osoba prema smrti i umiranju (The opinions of older people on death and dying).

You are kindly invited to read and ponder on the topical subjects that are brought about ageing and old age, since ageing is an issue that is common to everyone. Regardless of gender, race, ethnicity and other social characteristics, we all grow older and get increasingly closer to the final period of life.

Guest editors: Jana Mali and Ana Štambuk

Ljubljana and Zagreb, 31st May 2019 